\title{
The Effectiveness of D2L System: An Evaluation of Teaching-Learning Process in the Kingdom of Saudi Arabia
}

\author{
Dr. Mohammed Al-Shehri \\ College of Computer and Information Sciences, Majmaah University, \\ Kingdom of Saudi Arabia
}

\begin{abstract}
High quality education could be achieved through an e-learning system as it increases the educational information accessibility, service availability and accuracy when compared to a conventional face-to-face teaching-learning approach. However, user acceptance is one of the key essentials for adoption and success of e-learning system. Many studies revealed that use of D2L application is one of the best tool in the adoption of teaching and learning methodologies and the effectiveness of this application has gained a demand within the last few years. This paper investigates the feasibility of applying UTAUT model on Desire2Learn (D2L) e-learning system in KSA. The main objective of this study is to evaluate the efficiency of D2L (elearning) system based on students acceptance. Questionaire method was employed to accomplish this study. Based on the (UTAUT) model the impact of trust on the adoption of e-learning systems' services from students' perception was studied. Feedback was collected from 213 students to carry out the study. The results of this study indicates that the services offered by D2L System has significant weightage on teaching-learning process in Saudi Arabia from the student perspective.
\end{abstract}

Keywords-e-learning; Desire2Learn (D2L); Unified Theory of Acceptance and Use of Technology (UTAUT)

\section{INTRODUCTION}

E-learning has attracted major attention from researchers globally. It is obvious that most of teachers and students are Internet users. The use of Internet has modernized teacher's and learner's approach. Teaching-learning professionals and developers in government and private organizations are contributing their best efforts to improve the effectiveness of their e-learning system. The youth of the country believes that the web based teaching-learning is more successful than old conventional teaching i.e. chalk and duster methods etc. Elearning system measures an immediate performance feedback of its users as it is a time saving tool that keeps the records of user's activity and continuously improve their professional skills as well. Numerous academic institutions around the world have implemented and adopted the currently available interactive e-learning systems and its services. Most of the universities are blending their traditional lecture with full or partial web based courses. Educational institutions intent to enhance their teaching-learning methodologies in order to provide the best services to their students and teachers. The process and operations of teaching-learning services are improved by using an e-learning system that enhances the information sharing among the students and teachers. E- learning system also helps in administering the educational services within an institution in professional, secure and time saving manner. It is customary to say that every technology has few shortcomings when viewed very precisely. E-learning environment in Saudi Arabia promotes web based teaching, however there are some drawbacks that arise on its way through its success.

In order to keep up with the pace of the technological revolution in the field of higher education it has become important to implement the latest e-learning system in different universities and colleges of Saudi Arabia. In the current era of technology students and teachers are well versed in using internet and social sites and hence involvment in any kind of online learning is very easy way to acquaint themselves with any kind of web based teaching-learning environment. E-learning system must have a comprehensive architecture that enables provison of information based on needs and requirements of the students and teachers unlike any content based system. Essential changes were experienced in education system globally by the advent of internet and elearning and the Saudi Arabian education system has also acquired the same. Hence e-learning system is identified as top priority for all education institutions in KSA. The adoption of any e-learning system and its services by its users is a measureable point and reflects the effectiveness for that elearning system. This paper attempts to investigate the impact of trust as an external factor to UTAUT model and attempts to study the effects that influence Saudi students to accept and use an e-learning system named "Desire2Learn" (D2L). UTAUT is a proven model that empirically combined eight main models of technology acceptance and their extensions. This research paper is divided over five sections including the current introduction section. Section II discusses about the literature review. Section III presents the methodologies used. Data analysis and results are depicted in section IV. Section V mentions about the interpretation of results from the previous section. Future work and conclusion are described in section VI and VII respectively.

\section{LITERATURE REVIEW}

\section{A. E-learning: A teaching-learning process}

E-learning is a new trend in the education transformation. Information Technology is Kingdom of Saudi Arabia has an objective to support knowledge transformation of educational 
institutions by creating teaching-learning materials online. Universities around the world are accepting this teachinglearning methodology in order to improve services delivery for teachers and learners and hence eventually reduce costs and enhance accuracy and effectiveness in the field of education. The government, private universities and colleges in KSA are determined to advance the traditional teaching methods by making use of current IT tools. In fact, there are many researchers who presented their idea concerning teaching-learning process. This section presents some of the past research done in the field of teaching-learning process.

Axel Bottcher [5] identified the different criteria for feedback techniques for specific teaching based on some teaching-learning situation and presents a classification scheme for feedback evaluation techniques. The level of time granularity of feedback loops with a reasonable amount of time and group sizes were introduced were discussed. A scale of different best feedback techniques was presented for helping the users in selecting the appropriate feedback technique that can fit best in their teaching-learning context. John Rosbottom [6] reviewed different learning tools and assessment models that enhance the effectiveness in teaching and learning practice. Factors that measure the effectiveness of teaching-learning process are: IT skills of teachers/learners; ability to design and develop e-learning infrastructure; maintenance of the system; reusability of e-learning resources in different learning situations. Also, small web 2.0 applications like twitter, delicious etc. are easy to adapt and reduce time spent on tasks, hence, increase the level of efficiency in teaching-learning environment.

Steven Lonn[7] examined undergraduate's perceptions and use of a Learning Management System (LMS) through an online survey at two campuses: residential campus (main campus of university) and commuter campus (smaller satellite campus of the university). It was notified that for material management activities (online reading, accessing lecture notes and supplementary materials for teaching and learning), the residential students rated higher than commuter students. The commuter campus students rated significantly higher than residential campus students for interactive teaching and learning activities like posting questions or discussions after finishing lecture from teachers. Finally, the results show that commuter students who seems to use the LMS for virtual learning, use the LMS just for interactions with their colleagues and instructors whom they do not have face-to-face interactions. Similarly, residential students use the LMS for teaching and learning materials. The students at both the campuses adopt the LMS but with different perspective.

E-learning becomes especially significant given its potential to reduce teachers/learners' time, costs and expand teaching-learning methodologies when compared to traditional modes of teaching. Santoso Wibowo[8] presents an approach for assessing the effectiveness of teaching-learning technologies for teaching distance mode students. The approach exactly has the ability to handle the presence of multiple conflicting criteria and the presence of subjectiveness and inaccuracy inherent in the human decision making process in a less demanding way. Decision maker's personal assessments was represented by approximated Linguistic variables that were based on Fuzzy numbers.

Azizah Suliman[2] introduced Embedded Systems Programming (ESP) module for teaching programming in Malaysian schools. The module was an embedded kit that used electronic components, such as DC motor, LED, 7segment display and LCD as output. The module was effectively used at four schools in Malaysia and learning outcomes were assessed based on survey questionnaires and observations by the teachers. ESP module proved to be a successful tool for teaching and learning process and attracted students for learning programming courses. Now days, government and private institutions around the world are increasingly adopting teaching-learning system to present and improve their skills online. It is a question of concern how effectively these e-learning systems are being used by the teachers and learners in education and knowledge sharing process.

\section{B. Unified Theory of Acceptance and Use of Technology (UTAUT)}

The Unified Theory of Acceptance and Use of Technology (UTAUT)[23] is one of the most successful acceptance model in the field of information and communication technology. The main aim of this technology acceptance model is to justify the intentions of a user(s) for using an Information System and further depicts the usage behavior of the users towards a system. Venkatesh et al. [23] built UTAUT integrated model architecture to show a clear sketch of the user's acceptance process than any other individual models had been able to do privously. Eight previously used models named: TAM, TAM2, TPB, TRA, the Motivational Model (MM), the Model of PC Utilization (MPCU), DOI and Social Cognitive Theory (SCT) were combined to produce a well defined integrated model. All models individually make an effort to estimate and prove user's behaviour using a range of different independent variables. Having a similiarities for theoretical and experimental among these previously discussed eight models a unified UTAUT acceptance model was created. The theory is build around the four key ideas (performance expectancy -PE, effort expectancy-EE, social influence-SI, and facilitating conditions -FC) that express the usage behavior and intention [23]. Gender, age, experience, and voluntariness of use are put forwards to bring about the effect of these four key ideas on usage intention and behavior as shown in Figure 1. The UTAUT model has six predictors of behavioral intention or usage - performance expectancy (PE), effort expectancy (EE), social influence (SI), facilitating conditions (FC), behavioral intention (BI) and use behavior (USE) of e-learning system. The predictors for e-learning system are defined as follows [23] (p. 447-453):

- Performance expectancy (PE): "is the belief of an individual that using a particular system will advantageous him or her to enhance in teachinglearning performance."

- Effort expectancy (EE): "is the belief of an individual that the use of a particular e-learning system will be effortless" 
- Social influence (SI): "is the change in an individual feel or behavior that comes from others believe or acceptance."

- Facilitating conditions (FC): "is the belief of an individual that the needed technical infrastructures/supports are available to use the elearning system."

- Behavioural Intention (BI): "is his/her inclination to engage in a system."

- Use behaviour of e-learning system (USE): "is a system usage behaviour by teachers and learners."

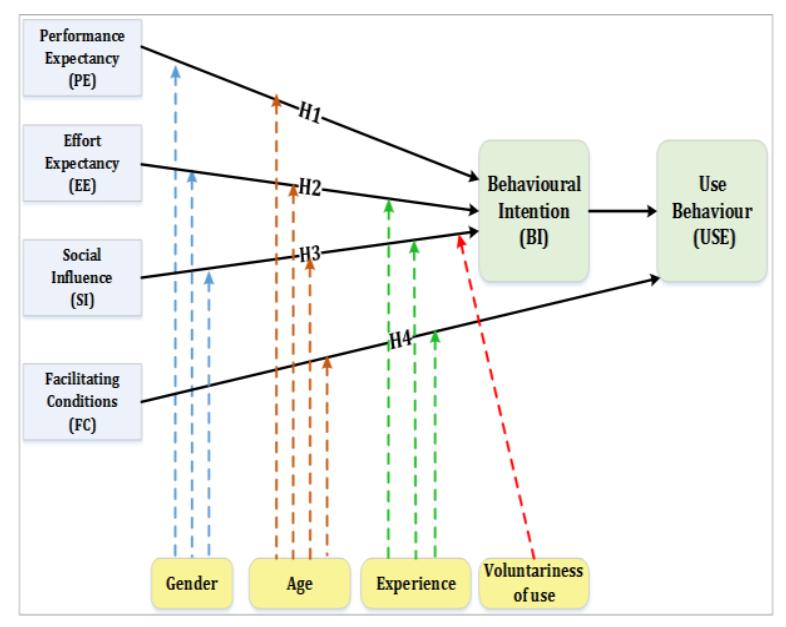

Fig. 1. UTAUT model (Venkatesh et. al., 2003)

\section{MethodOLOGY}

\section{A. Research Model and Hypothesis}

The main objective of this research work is to analyze the effect of confidence on the intention of Saudi students getting used to e-learning system. The research model for this study is shown in Figure 2. The constructs incorporated in the research model were drawn from the variables used in the [23] study as shown earlier. The researchers hypothesized relationships between different variables are as follows:

TABLE I. STUDY HYPOTHESIS

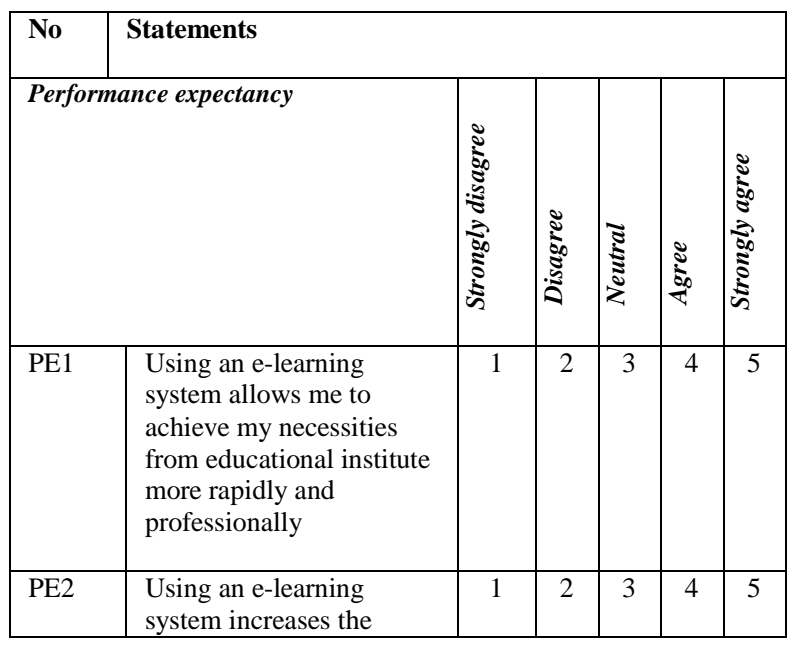

\begin{tabular}{|c|c|c|c|c|c|c|}
\hline & $\begin{array}{l}\text { equity between all } \\
\text { students }\end{array}$ & & & & & \\
\hline PE3 & $\begin{array}{l}\text { Using an e-learning } \\
\text { system saved student's } \\
\text { learning time. }\end{array}$ & 1 & 2 & 3 & 4 & 5 \\
\hline PE4 & $\begin{array}{l}\text { Using an e-learning } \\
\text { system increases the } \\
\text { quality of services }\end{array}$ & 1 & 2 & 3 & 4 & 5 \\
\hline \multicolumn{7}{|c|}{ Effort Expectancy } \\
\hline EE1 & $\begin{array}{l}\text { Learning through e- } \\
\text { learning system is easy. }\end{array}$ & 1 & 2 & 3 & 4 & 5 \\
\hline EE2 & $\begin{array}{l}\text { Using e-learning system's } \\
\text { services is easy. }\end{array}$ & 1 & 2 & 3 & 4 & \\
\hline EE3 & $\begin{array}{l}\text { It is easy for me to become } \\
\text { skillful at using an e- } \\
\text { leaning system. }\end{array}$ & 1 & 2 & 3 & 4 & 5 \\
\hline EE4 & $\begin{array}{l}\text { I am able to access learning } \\
\text { services easily by using an } \\
\text { e-learning system }\end{array}$ & 1 & 2 & 3 & 4 & 5 \\
\hline \multicolumn{7}{|c|}{ Social Influence } \\
\hline SI1 & $\begin{array}{l}\text { People who are nearer to } \\
\text { me suggest me to use the e- } \\
\text { learning system }\end{array}$ & 1 & 2 & 3 & 4 & \\
\hline SI2 & $\begin{array}{l}\text { People who influence my } \\
\text { behavior suggest me to use } \\
\text { e-learning system. }\end{array}$ & 1 & 2 & 3 & 4 & 5 \\
\hline SI3 & $\begin{array}{l}\text { I would use the e-learning } \\
\text { system if my friends and } \\
\text { colleagues used them } \\
\text { effectively }\end{array}$ & 1 & 2 & 3 & 4 & 5 \\
\hline SI4 & $\begin{array}{l}\text { The educational institute } \\
\text { encourage students to make } \\
\text { use of e-learning system. }\end{array}$ & 1 & 2 & 3 & 4 & 5 \\
\hline \multicolumn{7}{|c|}{ Facilitating Conditions } \\
\hline $\mathrm{FC} 1$ & $\begin{array}{l}\text { There are enough IT } \\
\text { resources available to make } \\
\text { use of an e-learning system }\end{array}$ & 1 & 2 & 3 & 4 & 5 \\
\hline $\mathrm{FC} 2$ & $\begin{array}{l}\text { Have enough knowledge to } \\
\text { use the e-learning system }\end{array}$ & 1 & 2 & 3 & 4 & 5 \\
\hline FC3 & $\begin{array}{l}\text { The needed technical } \\
\text { support is available for the } \\
\text { assistance to use the e- } \\
\text { learning system }\end{array}$ & 1 & 2 & 3 & 4 & 5 \\
\hline \multicolumn{7}{|c|}{ Behavioral Intention } \\
\hline BI1 & $\begin{array}{l}\text { I intend to use the e- } \\
\text { learning system services in } \\
\text { the next } 12 \text { months }\end{array}$ & 1 & 2 & 3 & 4 & 5 \\
\hline $\mathrm{BI} 2$ & $\begin{array}{l}\text { I predict I will use the } \\
\text { services offered by e- } \\
\text { learning system in the next } \\
12 \text { months }\end{array}$ & 1 & 2 & 3 & 4 & 5 \\
\hline BI3 & $\begin{array}{l}\text { I plan to use the e-learning } \\
\text { system in the next } 12 \\
\text { months }\end{array}$ & 1 & 2 & 3 & 4 & 5 \\
\hline \multicolumn{7}{|c|}{ Use Behavior of e-learning system } \\
\hline $\begin{array}{l}\text { USE } \\
1\end{array}$ & $\begin{array}{l}\text { I really want to use e- } \\
\text { learning system to perform } \\
\text { my educational requests }\end{array}$ & 1 & 2 & 3 & 4 & 5 \\
\hline $\begin{array}{l}\text { USE } \\
2\end{array}$ & $\begin{array}{l}\text { I frequently use e-learning } \\
\text { systems' services }\end{array}$ & 1 & 2 & 3 & 4 & 5 \\
\hline $\begin{array}{l}\text { USE } \\
3\end{array}$ & $\begin{array}{l}\text { I use services offered by e- } \\
\text { learning system on a } \\
\text { regular basis }\end{array}$ & 1 & 2 & 3 & 4 & 5 \\
\hline $\begin{array}{l}\text { USE } \\
4\end{array}$ & $\begin{array}{l}\text { Most of my educational } \\
\text { requests done through e- } \\
\text { learning system }\end{array}$ & 1 & 2 & 3 & 4 & 5 \\
\hline
\end{tabular}




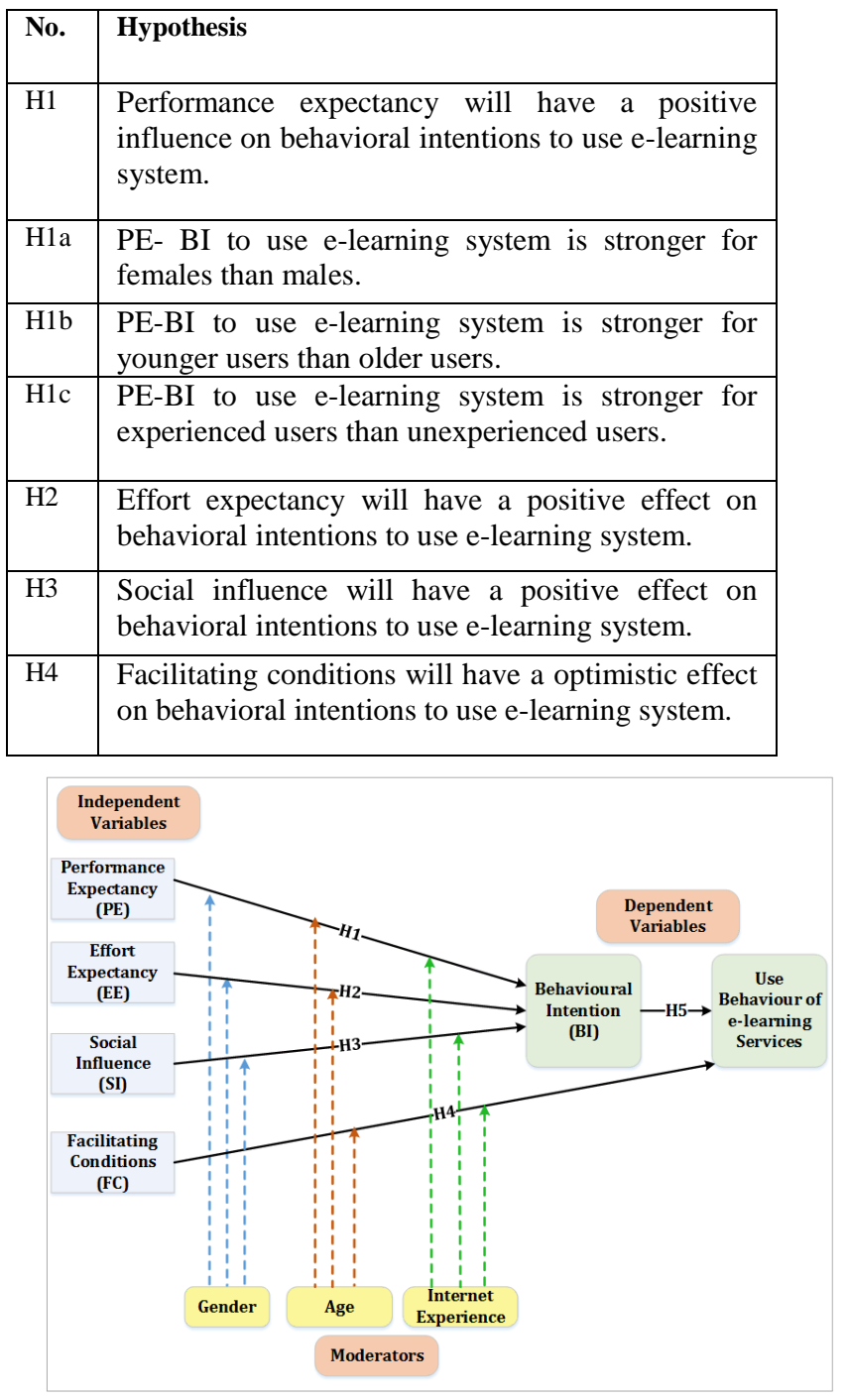

Fig. 2. Research Model

\section{B. Data Collection}

In this quantitative study, the questionnaire was used to find out the factors that effect the acceptance and use of the elearning systems' services in the public institutions in KSA by utilizing the proposed UTAUT model. Several researchers employed this technique to study the adoption of e-learning system for example [24], [25], [26], [9], [27], [28].

\section{DATA ANALYSIS AND RESULT}

The survey questionnaires were distributed among the Saudi students in three big universities of Saudi Arabia. Statistical Packages for Social Science (SPSS) was used to analyze the data. For analyzing the hypothesized relationships between different variables of the model, Structural equation modeling (SEM) technique is implemented. Structural Equation Modeling (SEM) is a statistical methodology that includes statistical methods and confirmatory approach to the structural analysis of data representing some phenomena [29]. The next part will explain the study analysis in more details.

\section{A. Descriptive Analysis}

The below Table 2 gives an overview of the Saudi students who participated in this research study in terms of the statistical information, such as gender, age and education level.

TABLE II. STATISTICAL INFORMATION OF STUDENTS

\begin{tabular}{|c|c|c|c|}
\hline \multicolumn{2}{|c|}{ Variable } & Frequency & Percent \\
\hline \multirow{2}{*}{ Gender } & Male & 85 & 39.9 \\
\cline { 2 - 4 } & Female & 128 & 60.1 \\
\hline \multirow{2}{*}{ Age } & $>20$ & 120 & 56.3 \\
\cline { 2 - 4 } & $21-30$ & 93 & 43.7 \\
\hline Education & Bachelor & 213 & 100 \\
\hline
\end{tabular}

\section{B. Measurement model}

In this study, the overall assessment of the measurement models and the convergent and discriminant validity check was done by confirmatory factor analysis. In the confirmatory factor analysis, average variance extracted (AVE) as a base was used to anaylyze converge validity. The explanatory power of all variable of the dimension to the average variations was calculated generally by AVE. Constructs have convergent validity when the AVE is above 0.50 and the composite reliability exceeds the criterion of 0.70 [30]. Table 3 shows the standardized loadings, composite reliabilities, and variance-extracted estimates and confirm that all tests support the convergent validity of the scales. 
TABLE III. RESULTS OF CONFIRMATORY FACTOR ANALYSIS

\begin{tabular}{|l|l|l|l|}
\hline Construct items & Std. & Composite & AVE \\
& loading & Reliability & \\
\hline Performance & & & \\
Expectancy & 0.88 & 0.91 & 0.87 \\
PE1 & 0.85 & & \\
PE2 & 0.79 & & \\
PE3 & 0.69 & & \\
PE4 & 0.88 & & \\
\hline Effort Expectancy & 0.79 & 0.81 & 0.79 \\
EE1 & 0.67 & & \\
EE2 & 0.68 & & \\
EE3 & & & \\
EE4 & & & \\
\hline Social Influence & 0.75 & 0.75 & 0.76 \\
SI1 & 0.71 & & \\
SI2 & 0.70 & & \\
SI3 & 0.68 & & \\
SI4 & & & \\
\hline Facilitating & & 0.82 \\
Conditions & 0.85 & 0.88 & \\
FC1 & 0.78 & & \\
FC2 & 0.75 & & \\
FC3 & 0.81 & \\
\hline Behavioral Intention & & 0.86 & \\
BI1 & 0.88 & & \\
BI2 & & \\
BI3 & 0.89 & \\
\hline Use Behaviour & & \\
USE1 & & \\
USE2 & & \\
USE3 & & \\
USE4 & & \\
\hline
\end{tabular}

The comparison of square roots of average variance extracted (AVE) to the inter-factor correlations between constructs evaluate the discriminant validity. Hair et al. [30] emphasized that the discriminant validity is supported for a model, if the AVE is higher than the squared inter-scale correlations of the construct. In Table 4, the discriminant validity is confirmed as all the square roots of AVEs (diagonal cells) are higher than the correlations between constructs.

TABLE IV. DISCRIMINANT VALIDITY RESUlTS FOR THE MEASUREMENT MODEL

\begin{tabular}{|cccccccc|}
\hline Construct & $\mathbf{1}$ & $\mathbf{2}$ & $\mathbf{3}$ & $\mathbf{4}$ & $\mathbf{5}$ & $\mathbf{6}$ & $\mathbf{7}$ \\
\hline $\mathbf{1 ~ P E}$ & 0.18 & 0.83 & & & & & \\
\hline 2 EE & 0.16 & 0.22 & 0.87 & & & & \\
\hline 3 FC & 0.14 & 0.27 & 0.50 & 0.90 & & & \\
\hline 4 SI & 0.28 & 0.31 & 0.30 & 0.25 & 0.91 & & \\
\hline 5 BI & 0.04 & 0.33 & 0.05 & 0.30 & 0.05 & 0.85 & \\
\hline 6 USE & 0.23 & 0.32 & 0.01 & 0.36 & 0.27 & 0.37 & 0.95 \\
\hline
\end{tabular}

C. Structural Model Testing

The fit indices are summarized in Table 5 while the suggested structural model is shown in Figure 3. Overall, the model showed a good level of fit: $(\chi 2=626.30$, df $=355$, $\chi 2 / \mathrm{df}=1.76, \mathrm{GFI}=0.91, \mathrm{TLI}=0.90, \mathrm{CFI}=0.94, \mathrm{IFI}=0.93$, RMSEA $=0.07$ ). According to the finding in Table 5, five out of the six path coefficients (hypotheses) were statistically significant and were considered meaningful (ranging from 0.34 to 0.62). The findings reveal that Performance Expectancy (PE) construct in the e-learning system positively predicted behavioral intention $(\mathrm{BI})$ construct $(0.34, \mathrm{p}<.001)$ thus supporting H1. Second, Effort Expectancy (EE) predict behavioral intent $(0.39, \mathrm{p}<.001)$ and provide its support for $\mathrm{H} 2$. Third, Social Influence (SI) also predict behavioral intent $(0.38, \mathrm{p}<.001)$ significantly and therefore, H3 was supported. Fourth, Facilitating Conditions (FC) positively predict behavioral intent $(0.48, \mathrm{p}<.001)$ thus supporting $\mathrm{H} 4$. Finally the fifth, Behavioural Intention (BI) positively predicted use behaviour (USE) $(0.62,<.001)$ and thus provide its full support for H5.

TABLE V. Structural Model Result

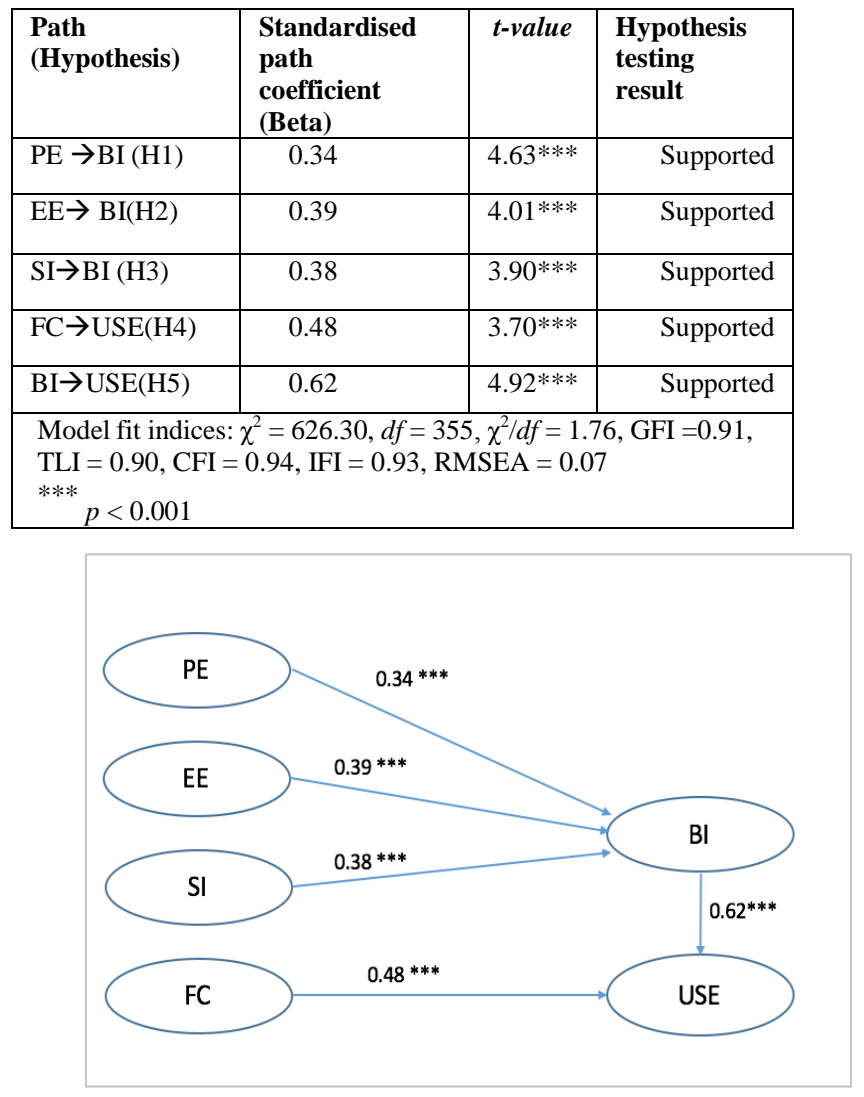

Fig. 3. Structural Model with standardized path coefficients

\section{The Effect of different Moderators}

This section presents the effect of moderators on different construct. Moderators are variables that affect the strength or weakness of relationships between independent and dependent constructs in the model [31]. According to Hair et al. [30], the relationship between independent and dependent variables could be stronger or weaker because of the effect of moderators. In this study, the moderators that have been investigated here are gender, age, and internet experiences. 
The results of moderating hypotheses are presented below:

1) Hla: The relationship between Performance expectancy and behavior intent varied significantly across experience groups $\left(\Delta \chi^{2}(1)=76.24, p=.001\right)$. The relationship between Performance Expectancy and behavior intent was statistically significant and stronger in the sample of experienced respondents $(\beta=.36, p=.001)$ than it was in the inexperienced sample of respondents $(\beta=.17, p=$ .001).As result of this finding, the moderating hypothesis of experience effect $(\mathrm{H} 1 \mathrm{c})$ is supported.

2) H1b: The relationship between Performance Expectancy and behavior intent varied significantly across age groups $\left(\Delta \chi^{2}(1)=44.27, p=.001\right)$. The relationship between Performance expectancy and behavior intent was statistically significant in the younger sample of respondents $(\beta=.31, p=$ $.001)$ and was stronger than the older sample of respondents $(\beta$ $=.11, p=.152)$. In summary, this results show that the hypothesis of experience effect (H1b) is supported.

3) Hlc: The relationship between Performace Expectancy and behavior intent varied significantly across experience groups $\left(\Delta \chi^{2}(1)=76.24, p=.001\right)$. The relationship between Performance Expectancy and behavior intent was statistically significant and stronger in the sample of experienced respondents $(\beta=.36, p=.001)$ than it was in the inexperienced sample of respondents $(\beta=.17, p=.001)$. As result of this finding, the moderating hypothesis of experience effect $(\mathrm{H} 1 \mathrm{c})$ is supported.

\section{INTERPRETATIONS OF RESULTS}

The study of factors that influence student's behavioural intention to accept and use of e-learning systems' services is very important in these days while Internet becomes increasingly more useful and many countries around the world provide their services electronically. This study examined the applicability of an UTAUT model for predicting the Saudi student's intention to adopt the services offered by D2L elearning system. The results of this research study supports most of the study hypothesis proposed earlier to this study. The impact of the factors and its effects on acceptance process explained in the study model can be categorized to significant and non-significant factors as follow:

The result seems to indicate that in order to increase elearning system usage among the students, the university/colleges should increase the student expectation in the university/college entities and in its e-systems as well its services. Six predictors of behavioral intention or usage performance expectancy, effort expectancy, social influence, facilitating conditions, behavioral intention and use behavior of e-learning system has been identified as main variables that play an key role in the acceptance of e-learning system [9]. Moreover, Gender, Age and Internet experience were found to be noteworthy moderators in terms of affecting the behavioural intention to use e-learning system in KSA.

\section{A. Performance Expectancy $(P E)$ had a positive impact}

influence on Behaviour Intention to use e-learning system.

This result emphasise that performance expectancy remains significant and a strong factor of behavioural intention [23].

B. Effort Expectancy (EE) had a optimistic impact on Behavioural Intention to use e-learning system and its services. This result reveal that effort expectancy is a significant factor of behavioural intention [23].

C. Facilitating Conditions (FC) had an optimistic result on Behavioural Intention to practise e-learning system. This result shows that effort expectancy is a significant predictor of behavioural intention [23].

D. Social Influence (SI) did not have any meaningful effect on Behavioural Intention for adopting an e-learning system and therefore its hypothesis has not been supported but it would be controlled by user's experience for Internet.

\section{FUTURE WORK}

The future work intents to include website quality as an independent variable into this research model. The UTAUT model will be applied to various other e-learning systems being used in other countries in order to develop a comparative methodology for ranking various e-learning systems based on UTAUT. The difference of student's behavior in different countries will also be incorporated in the future study.

\section{CONCLUSION}

This study provides an understanding of the determinants of confidence in e-learning system. The analysis revealed that the student's trust on e-learning systems has positive and significant. Influence on the behavioural intention to use elearning system. This research was conducted in the Kingdom of Saudi Arabia, so the analysis is based on the perception of the Saudi students. Hence the result of the study is limited to one Arab country because student's behavior differs between countries and nations. Another limitation is that this study was a cross-sectional investigation in which the data was gathered just once over a period of time. Contrary to longitudinal studies that determine behavioural intention and usage in different times.

\section{REFERENCES}

[1] Heeks, R. Most eGovernment-for-Development Projects Fail: How Can Risks be Reduced?" iGovernment Working Paper Series, 2003, pp.14.

[2] Azizah Suliman and Surizal Nazeri. The effectiveness of Teaching and Learning Programming using Embedded System. IEEE 2012, pp 32-36.

[3] Kaliannan, Halimah, Raman. Technology adoption in the public sector: An exploratory study of e-government in Malaysia. International Conference on Theory and Practice of Electronic Governance, ICEGOV 2007, Macao, December 10-13, 2007, pp. 221-224.

[4] Moon, Norris F. Does managerial orientation matter? The adoption of reinventing government and e-government at the municipal level. Information Systems Journal, 14 jan, 2005, pp 43-60.

[5] Axel Bottcher, Feedback Techniques for the Evaluation of Teaching Effectiveness. Global Engineering Education Conference (EDUCON), IEEE 2015, pp 668-675.

[6] John Rosbottom, Jean-Marc Lecarpentier, Collaborative web tools to enhance efficiency and effectiveness in learning and teaching, IEEE 2010, pp 560-566.

[7] Steven Lonn, Stephanie D. Teasley, Andrew E. Krumm. Investigating Undergraduates' Perceptions and Use of a Learning Management 
System: A Tale of Two Campuses, Annual Meeting of the American Educational Research Association San Diego, California, April 16, 2009.

[8] Santoso Wibowo, Srimannarayana Grandhi and Ritesh Chugh Assessing the Effectiveness of Learning and Teaching Technologies for Teaching Distance Mode Students in Higher Education, Conference on e-Learning, e-Management and e-Services (IC3e), IEEE 2014, pp 24-29.

[9] Carter, L., \& Belanger, F. The utilization of e-government services citizen trust, innovation and acceptance factors. Information Systems Journal, 15(1), 2005,pp 5-25.

[10] Rotter, J. B. A New Scale for the Measurement of Interpersonal Trust. Journal of Personality. 35, 1967, pp 65-665.

[11] McKnight, D. H., Choudhury, V., \& Kacmar, C. Developing and validating trust measures for e-commerce: An integrative typology. Information systems research, 13 (3), 2002, pp 334-359.

[12] Pavlou, P. Consumer acceptance of electronic commerce: integrating trust and risk with the acceptance model. International Journal of Electronic Commerce, 7(3), 2003, pp 69-103.

[13] Mayer, R.C., Davis, J.H., Schoorman, F.D. An integrative model of organizational trust. Academy of Management Review 20 (3), 1995, pp709-734.

[14] Reichheld, P. \& Schefter, P. E-loyalty: your secret weapon on the web. Harvard Business Review. 78(4), 2000, pp105-113.

[15] Gefen, D., Karahanna, E., \& Straub, D. Trust and TAM in online shopping: an integrated model. MIS Quarterly, 27 (1), 2003, pp 51-90.

[16] Holsapple, C., \& Sasidharan, S. The dynamics of trust in B2C ecommerce: a research model and agenda. Information Systems and EBusiness Management, 3(4), 2005, pp 377-403.

[17] Pavlou, P., \& Fygenson, M. Understanding and predicting electronic commerce adoption: an extension of the theory of planned behavior. MIS Quarterly, 30(1), 2006, pp115.

[18] Belanger, F. \& Carter, L. Trust and risk in e-government adoption, Journal of Strategic Information Systems vol. 17, 2008, pp 165-176.

[19] Warkentin, M., Gefen, D., Pavlou, P., \& Rose, M. Encouraging citizen adoption of e-government by building trust. Electronic Markets, 12(3), 2002, pp 157-162.

[20] Welch, E., Hinnant, C., \& Moon, M. Linking citizen satisfaction with egovernment and trust in government. Journal of Public Administration Research and Theory, 15(3), 2005, pp 371-391.

[21] Oxendine, M. S. The importance of trust and community in developing and maintaining a community electronic network. International Journal of Human-Computer Studies, 58(6), 2003, pp 671-196.

[22] Wang, H., Yang, H. The role of personality traits in UTAUT model under online stocking. Contemporary Management Research 1 (1), 2005, pp 69-82.

[23] Venkatesh, V., Morris, M., Davis, G., and Davis, F. User acceptance of information technology: toward a unified view. MIS Quarterly, 27 (3), 2003,pp 425-478.

[24] West, D. M. Digital government: technology and public sector performance. Princeton, NJ: Princeton University Press, 2005.

[25] Carter, L. \& Belanger, F. Citizen Adoption of Electronic Government Initiatives. Proceedings of the 37th Hawaii International Conference on System Sciences. IEEE, 2004.

[26] Carter, L., Belanger, F. The influence of perceived characteristics of innovating on e-Government adoption. Electronic Journal of eGovernment 2 (1), 2003, pp 11-20.

[27] Akman, I. Yazici, A. Mishra, A. Arifoglu,A. E-Government: A global view and an empirical evaluation of some attributes of citizens. Government Information Quarterly, 22 (2), 2005, pp 239-257.

[28] Reddick, C.G. Citizen interaction with e-government: from the street to servers? Government Information Quarterly, 21 (1), 2005, pp 51-64.

[29] Kline, R. B. Principles and practice of structural equation modeling (2nd ed.). New York: Guiford, 2005.

[30] Hair, J. F., Anderson, R. E., Tatham, R. L., \& Black, W. C. Multivariate Data Analysis (6th ed.). Upper Saddle River, N.J.: Pearson Prentice Hall, 2006.

[31] Serenko, A, Turel, O \& Yol, S. Moderating roles of user demographics in the American customer satisfaction model within the context of mobile services. Journal of information technology management, 17 (4), 2006.

[32] Colesca, S.E. \& Dobrica, L. Adoption and use of e-government services: The case of Romania. Journal of Applied Research and Technology, 6(3), 2008,pp 204-217.

[33] Tan, C.W., Benbasat. I., \& Cenfetelli, R.T . Building citizen trust towards e-government services: Do high quality website matter? Proceedings of the $41^{\text {th }}$ Hawaii International Conference on System Sciences (HICSS'08), 2008.

[34] Mofleh, S.I. \& Wanous, M. Understanding factors influencing citizens' adoption of e-government services in the developing world: Jordan as a case study. INFOCOM-Journal of Computer Science, 7(2), 2008, pp 111.

[35] Lee, C.B. \& Lei, U.L. Adoption of e-government services in Macao. Proceedings of the $1^{\text {st }}$ International Conference on Theory and Practice of Electronic Governance, ACM International Conference Proceeding Series, 232, 2007, pp 217-220

[36] Hung. S.Y., Chang, C.M. \& Yu, T.Y. Determinants of user acceptance of the e-government services: The case of online tax filing and payment system. Government Information Quarterly, 23(1), 2006, pp 97-122.

[37] Thomaz E.V. Silva, F. HerbertL. Vasconcelos, Andre L.F. Almeida, Joao C.M. Mota. Multivariate Analysis for Students' Evaluation of Teaching Effectiveness in Tele informatics Engineering. International Conference on Teaching, Assessment, and Learning for Engineering (TALE), IEEE, 2012, pp H1A-6 